\title{
INTERNALISASI KARAKTER PEDULI LINGKUNGAN MELALUI PEMBELAJARAN GEOGRAFI DI SEKOLAH ADIWIYATA (STUDI KASUS: SMAN 11 PADANG)
}

\author{
Dewi Yulia Noviarti ${ }^{1}$, Yurni Suasti ${ }^{2}$, Dedi Hermon ${ }^{2}$ \\ Program Studi Pendidikan Geografi \\ Fakultas Ilmu Sosial Universitas Negeri Padang \\ Email: yulianoviarti@gmail.com
}

\begin{abstract}
Abstrak
Penelitian ini bertujuan untuk mendeskripikan dan menganalisis muatan nilai karakter peduli lingkungan dalam RPP, transformasi nilai, transaksi nilai, dan transinternalisasi nilai. Jenis penelitian ini adalah deskriptif kualitatif. Subjek penelitian yaitu guru geografi yang mengajar di kelas XI IS 2 SMAN 11 Padang. Metode pengumpulan data dengan observasi, wawancara, dan analisis dukomen. Teknik analisis data berupa reduksi data, penyajian data, dan penarikan kesimpulan. Keabsahan data menggunakan triangulasi sumber dan teknik. Hasil penelitian menunjukkan bahwa: (1) Guru belum memasukkan nilai karakter peduli lingkungan dalam RPP. (2) Transformasi nilai dilaksanakan guru dengan memperkenalkan nilai karakter peduli lingkungan di kelas. (3) Transaksi nilai dilaksanakan guru dengan membiasakan peserta didik melaksanakan kegiatan peduli lingkungan di kelas. (4) Trans-internalisasi nilai dilaksanakan guru dengan memberikan teladan dalam melaksanakan nilai karakter peduli lingkungan di kelas.
\end{abstract}

Kata kunci: Internalisasi, karakter peduli lingkungan, pembelajaran geografi

\begin{abstract}
This study aimed to describe and analyze the content of character care for the environment in the RPP, transformation of value, transaction of value, transinternalization of value. This research is a descriptive qualitative research. The research subject was geography teacher who taught in class XI IS 2 of SMAN 11 Padang. The Methods of data collection with observation, interview, and document analyzes. The techniques of data analyze were data reduction, data display, and verification. The validity of data used triangulation of sources and technique. The results of study indicated that: (1) The teacher does not yet to include the value of character care for the environment in the RPP. (2) Transformation of value was habituation by the teacher to students for introducing the value of character care for the environment in the classroom. (3) The transaction of value was implemented by the teacher to familiarize students with activities for care the environment in the classroom. (4) The trans-internalization of value was imolemented by the teacher to provide the example of caring the environment in the classroom.
\end{abstract}

Key word: Internalization, character care for the environment, learning of geography

\footnotetext{
${ }^{1}$ Mahasiswa Jurusan Geografi FIS UNP

${ }^{2}$ Dosen Pembimbing Jurusan Geografi FIS UNP
} 


\section{PENDAHULUAN}

Perilaku masyarakat yang belum mampu mengelola sampah dengan baik menjadi masalah yang serius. Minimnya kesadaran masyarakat merupakan faktor utama penyebab munculnya permasalahan lingkungan. Apabila permasalahan ini diabaikan, maka akan berdampak pada terganggunya kebersihan lingkungan dan kesehatan masyarakat.

Untuk itu perlu upaya penanaman karakter peduli lingkungan. Salah satunya melalui pendidikan di sekolah. Melalui pendidikan, potensi manusia akan tumbuh dan berkembang menjadi insan yang tertata pola pikirnya, termanifestasikan sikap dan tingkah laku baiknya.

Pendidikan mengarahkan manusia dari sebelumnya tidak mengetahui menjadi tahu, sebelumnya berperilaku kurang baik menjadi berperilaku baik. Pendidikan memfasilitasi manusia menjadi dewasa, bertanggungjawab, jujur, beradab, dan berkarakter.

Penanaman karakter peduli lingkungan dalam pendidikan bertujuan agar peserta didik memiliki pengetahuan dan kesadaran bahwa setiap individu memiliki peran dengan lingkungan di sekitarnya dan memiliki keterampilan dalam menciptakan perubahan yang baik bagi lingkungan. Untuk melatih dan membiasakan peserta didik berperilaku baik terhadap lingkungan sekitarnya maka perlu ditanamkan karakter peduli lingkungan melalui pembelajaran di sekolah.

Kebijakan yang dibuat oleh pemerintah melalui Peraturan Menteri Lingkungan Hidup No. 5 Tahun 2013 diterjemahkan menjadi program sekolah Adiwiyata. Hal ini sejalan dengan Permendiknas No. 23 Tahun 2016 yang menjelaskan mengenai tujuan pembelajaran geogafi yaitu menampilkan perilaku peduli terhadap lingkungan.

Dari seluruh mata pelajaran yang diajarkan di tingkat SMA, mata pelajaran Geografi memiliki tanggung jawab yang lebih besar dalam menanamkan nilai karakter peduli lingkungan karena memiliki misi menjaga lingkungan. Hal ini tercantum dalam lampiran Permendikbud No. 59 Tahun 2014 yang menjelaskan bahwa mata pelajaran Geografi bertujuan menampilkan perilaku peduli terhadap lingkungan hidup dan memanfaatkan sumber daya alam secara arif serta memiliki toleransi terhadap keragaman budaya bangsa.

Dalam hal ini, SMAN 11 Padang adalah salah satu sekolah yang mampu memperoleh pencapaian adiwiyata mandiri dan berprestasi dalam pengembangan kebijakan sekolah peduli dan berbudaya lingkungan. SMAN 11 Padang memiliki misi yakni mewujudkan pembelajaran berbasis lingkungan hidup dalam rangka mencegah kerusakan lingkungan hidup.

Berdasarkan pemaparan di atas, seharusnya pembelajaran yang dilaksanakan guru di sekolah adiwiyata, sudah berorientasi pada penanaman karakter peduli lingkungan terutama guru geografi. Oleh karena itu, untuk melihat bagaimana proses pembelajaran yang dilaksanakan oleh guru geografi dalam menanamkan karakter peduli lingkungan maka dalam kajian ini 
membahas mengenai internalisasi karakter peduli lingkungan melalui pembelajaran geografi di sekolah adiwiyata (studi kasus: SMAN 11 Padang).

Tulisan ini bertujuan untuk mendeskripsikan dan menganalisis: (1) muatan nilai karakter peduli lingkungan dalam RPP geografi, (2) transformasi nilai karakter peduli lingkungan melalui pelaksanaan pembelajaran geografi (pendahuluan, inti, dan penutup), (3) transaksi nilai karakter peduli lingkungan melalui pelaksanaan pembelajaran geografi (pendahuluan, inti, dan penutup), dan (4) transinternalisasi nilai karakter peduli lingkungan melalui pelaksanaan pembelajaran geografi (pendahuluan, inti, dan penutup).

Menurut Robert dalam Ulum, Bahrul (2017:34) menjelaskan bahwa internalisasi adalah menyatunya nilainilai pada diri seseorang. Sejalan dengan pengertian tersebut, Ihsan dalam Ulum, Bahrul (2017:35) memaknai internalisasi sebagai upaya yang dilakukan untuk memasukkan nilai-nilai ke dalam diri seseorang sehingga menjadi miliknya. Pengertian ini mengisyaratkan bahwa pengetahuan dan pemahaman tentang nilai-nilai yang telah diperoleh mesti tercermin dalam sikap dan tingkah laku sehari-hari dan dilaksanakan dengan konsisten sehingga menjadi karakter yang bersifat permanen (kepribadian).

Pada sekolah Adiwiyata yang memuat karakter peduli lingkungan, di dalamnya juga terkandung nilai-nilai seperti yang di paparkan oleh Samani, Muchlas., dkk (2012:41) yaitu: perhatian (attentiveness), kesediaan (availability), kepedulian (careness), kewarganegaraan (citizenship or civic), komitmen (commitment), keberanian (courage), keingintahuan (courisity), kritis (critical), dapat diandalkan (dependability), kerajinan (diligence), daya upaya atau usaha (effort), keadilan (justice), kelembutan hati (meekness), moderasi atau suka hal yang sedangsedang (moderation), kerapian (oderliness), sifat menghormat/ menghargai, menghargai lingkungan (respect for environment), menghargai kesehatan (respect for healt), pertanggungjawaban (responsibility), amanah atau dapat dipercaya (trusworthiness), dan kearifan atau kebijaksanaan (wisdom). Himpunan dari nilai-nilai inilah yang nantinya akan ditanamkan pada peserta didik di sekolah melalui program sekolah maupun pembelajaran yang berlangsung di sekolah.

Menurut Muhaimin dalam Sahlan, Asmaul., dkk (2016:31-33), ada tiga tahap proses internalisasi pendidikan karakter. Pertama, transformasi nilai (pengetahuan). Transformasi nilai merupakan suatu proses yang dilakukan oleh guru dalam menyampaikan nilainilai (kebaikan nilai, keburukan nilai, dan manfaat nilai). Pada tahap ini hanya terjadi komunikasi verbal yang bersifat satu arah dari guru kepada peserta didik. Nilai-nilai yang diberikan hanya pada ranah kognitif. Kedua, transaksi nilai (pembiasaan). Pada tahap ini terjadi komunikasi dua arah, atau interaksi timbal balik antara guru dengan peserta didik. Inti pada tahap ini adalah pembiasaan yang dilakukan oleh guru dan mendapat respon dari peserta didik. 
Respon yang diberikan peserta didik bisa beragam. Ada peserta didik yang menolak, menerima, dan acuh tak acuh terhadap nilai-nilai yang dibiasakan oleh guru. Ketiga, trans-internalisasi nilai (keteladanan). Tahap ini jauh lebih mendalam dari tahap transaksi. Pada tahap ini bukan hanya dilakukan dengan komunikasi verbal tetapi juga sikap mental dan kepribadian. Dalam hal ini guru mesti memperhatikan sikap dan perilakunya agar tidak bertentangan dengan nilai-nilai yang baik sebab seluruh aspek yang ada pada guru akan mempengaruhi kepribadian peserta didik.

\section{METODE PENELITIAN}

Jenis penelitian ini adalah deskriptif kualitatif. Penelitian ini dilakukan di SMAN 11 Padang yang beralamat di Jl. Raya Padang - Painan KM.20, Teluk. Kabung Utara, Bungus Teluk. Kabung, Kota Padang, Sumatera Barat. Subjek penelitian adalah guru geografi yang mengajar di kelas XI IS 2 SMAN 11 Padang. Penelitian dilaksanakan pada tanggal 9 Juni s/d 25 Juli 2018.

Metode pengumpulan data dilakukan dengan (1) observasi terhadap pelaksanaan pembelajaran geografi di kelas XI IS 2, (2) wawancara dengan peserta didik, dan (3) analisis dokumen berupa perangkat pembelajaran (RPP dan silabus) dan dokumentasi berupa foto yang diambil saat kegiatan pembelajaran berlangsung. Teknik analisis data menurut Matthew B. Miles dan A. Michael Huberman dalam Sugiyono (2010:337) dilakukan secara interaktif dan berlangsung secara terus- menerus hingga datanya jenuh. Langkahlangkah yang dilakukan dalam menganalissi data diantaranya reduksi data, penyajian data, dan penarikan kesimpulan. Keabsahan data menggunakan triangulasi sumber dan triangulasi teknik.

\section{HASIL DAN PEMBAHASAN}

\section{Analisis Muatan Nilai Karakter Peduli Lingkungan dalam Komponen RPP Geografi}

Dalam penelitian ini penulis menganalisis komponen RPP geografi berdasarkan indikator komponen RPP berkarakter yang ditetapkan oleh Kemendikbud (2010). RPP yang dianalisis adalah RPP yang telah disusun oleh guru pada KD 3.1 Memahami kondisi wilayah dan posisi strategis Indonesia sebagai poros maritim dunia.

Hasil analisis komponen RPP belum ditemukan nilai karakter peduli lingkungan di dalam rumusan tujuan pembelajaran, pendekatan/metode pembelajaran, langkah-langkah pembelajaran, penilaian pembelajaran, dan bahan ajar dalam RPP.

Hal ini membuktikan bahwa hidden curriculum yang terdapat dalam kurikulum 2013 yang berbasis karakter sudah secara otomatis dalam pelaksanaannya. Hal ini sudah termuat juga dalam kompetensi inti yang dirancang dalam empat kelompok yang saling terkait yaitu: (1) sikap keagamaan yakni untuk membentuk peserta didik yang beriman dan bertaqwa, (2) sikap sosial yakni untuk membentuk peserta didik yang berakhlak mulia, mandiri, demokratis, dan bertanggung jawab, (3) 
pengetahuan, dan (4) penerapan pengetahuan.

\section{Transformasi Nilai Karakter Peduli Lingkungan Melalui Pembelajaran Geografi (Pengetahuan)}

Hasil penelitian terhadap pelaksanaan pembelajaran geografi di kelas XI IS 2 pada KD 3.1 menunjukkan bahwa guru sudah melaksanakan transformasi nilai karakter peduli lingkungan (pengetahuan) namun hanya pada kegiatan pendahuluan saja. Nilai karakter peduli lingkungan yang ditanamkan adalah menjaga kebersihan dan membuang sampah pada tempatnya. Pada kegiatan inti dan penutup, guru sama sekali belum menyentuh nilai karakter peduli lingkungan.

Pada kegiatan pendahuluan ini, guru mulai memperkenalkan nilai karakter peduli lingkungan. Guru menjelaskan kepada peserta didik mengenai pencapaian adiwiyata oleh sekolah dan menjelaskan pentingnya menjaga kebersihan dan membuang sampah pada tempatnya.

Pada kegiatan inti, guru sama sekali belum menyentuh pada aspek penanaman nilai karakter peduli lingkungan. Hal ini dibuktikan dari hasil pengamatan penulis saat kegiatan inti berlangsung, yakni: (1) Pada saat menjelaskan materi, guru belum mengaitkan materi dengan nilai karakter peduli lingkungan. (2) Guru juga belum ada memasukkan isu ligkungan hidup dalam materi pembelajaran. (3) Perserta didik dilibatkan untuk aktif mengikuti pembelajaran melalui diskusi kelompok namun belum menyentuh kepada nilai karakter peduli lingkungan. (4) Respon yang diberikan guru berupa ulasan terhadap pertanyaan disukusi peserta didik belum menyentuh kepada nilai karakter peduli lingkungan. (5) Guru memberikan penguatan dengan menjelaskan kembali materi yang telah didiskusikan dengan memasukkan nilai karakter namun penjelasan tersebut belum menyentuh kepada nilai karakter peduli lingkungan.

Pada kegiatan penutup, guru sama sekali belum membahas nilai karakter peduli lingkungan. Dari pengamatan penulis, guru membuat rangkuman dengan melibatkan peserta didik namun rangkuman tersebut belum terkait dengan nilai karakter peduli lingkungan. Guru juga belum ada memberikan tugas rumah kepada peserta didik sebab diskusi kelompok di kelas masih berlangsung sampai pertemuan berikutnya.

Transformasi nilai karakter peduli lingkungan yang dilakukan oleh guru diterima baik oleh peserta didik. Peserta didik merasa sangat senang saat guru menjelaskan mengenai pencapaian SMAN 11 Padang menjadi sekolah adiwiyata dan pentingnya menjaga kebersihan lingkungan. Peserta didik juga merasakan banyak manfaat yang diperoleh. Perasaan senang ini diekspresikan dengan berusaha memperhatikan penjelasan dari guru dengan baik dan tidak ribut di kelas. Dengan begitu peserta didik merasa semakin disadarkan dan muncul kepekaan untuk peduli dengan lingkungan.

Peserta didik juga memberikan pandangannya terhadap pentingnya nilai karakter peduli lingkungan. Peserta didik 
merasakan betul arti penting lingkungan bagi kehidupan karena lingkungan yang bersih dan terjaga akan menguntungkan, lebih nyaman dan damai. Dimanapun berada, di sekolah atau di luar sekolah karakter peduli lingkungan mesti dibiasakan dan tentunya dimulai dari diri sendiri.

Transformasi nilai sebagai tahap awal dalam proses internalisasi akan lebih maksimal apabila guru menggunakan pendekatan/metode yang relevan untuk pengembangan karakter peduli lingkungan. Hal ini diperkuat dengan pernyataan Suasti, Yurni (2018), "The internalization process in character value of care for the environment will better be using cooperative approach". Proses internalisasi nilai karakter peduli lingkungan akan lebih baik menggunakan pendekatan kooperatif. Melalui pendekatan ini diharapkan mampu memberi ruang bagi terlaksananya interaksi antara pendidik dan peserta didik dalam proses penanaman nilai karakter peduli lingkungan.

\section{Transaksi Nilai Karakter Peduli Lingkungan Melalui Pembelajaran Geografi (Pembiasaan)}

Hasil penelitian terhadap pelaksanaan pembelajaran geografi di kelas XI IS 2 pada KD 3.1 menunjukkan bahwa guru sudah melaksanakan transaksi nilai karakter peduli lingkungan pada kegiatan pendahuluan, inti, dan penutup. Nilai karakter peduli lingkungan yang ditanamkan adalah menjaga kebersihan dan kerapian kelas, membuang sampah pada tempatnya dan menjaga kebersihan diri.

Pada kegiatan pendahuluan, guru menanamkan nilai karakter peduli lingkungan yaitu menjaga kebersihan kelas, membuang sampah pada tempatnya, dan menjaga kebersihan diri. Setelah mengucapkan salam dan berdo'a, guru mengkondisikan peserta didik agar membersihkan kelas dari sampah dan membuangnya pada tempat sampah yang telah disediakan di dalam kelas. Guru juga meminta kepada petugas piket kebersihan pada saat itu untuk membersihkan bagian teras kelas yang masih kotor.

Pada kegiatan inti, guru menanamkan nilai karakter peduli lingkungan yaitu menjaga kebersihan dan kerapian kelas. Setelah penampilan hasil diskusi kelompok 1 dan 4 dipresentasikan, guru meminta peserta didik untuk menyusun kembali meja dan kursi ke tempat semula.

Pada kegiatan penutup, guru menanamkan nilai karakter peduli lingkungan yaitu menjaga kebersihan kelas dan membuang sampah pada tempatnya. Sebelum pelajaran ditutup, guru meminta peserta didik untuk kembali membersihkan kelas dari sampah dan mengingatkan peserta didik agar membuang sampah yang berserakan ke tempat sampah yang telah disediakan di dalam kelas.

Transaksi nilai karakter peduli lingkungan yang dilakukan oleh guru ditunjukkan dengan sikap antusias peserta didik dalam melaksanakan kegiatan peduli lingkungan di kelas berupa kegiatan membersihkan kelas, merapikan kelas, dan membuang sampah 
pada tempatnya. Sikap antusias peserta didik ini menunjukkan bahwa peserta didik sudah memperlihatkan respon yang baik terhadap pembelajaran afektif yang dilaksanakan oleh guru.

Pembiasaan untuk menjaga lingkungan juga diaplikasikan oleh peserta didik dalam kehidupan seharihari, seperti membuang sampah yang ditemui pada tempatnya, membersihkan kamar, rumah, sekolah, dan lingkungan sekitar. Bila sudah melakukannya dari hal terkecil dan terdekat maka akan terbiasa melakukan hal yang besar dimana saja berada.

\section{Trans-internalisasi Nilai Karakter Peduli Lingkungan Melalui Pembelajaran Geografi (Keteladanan)}

Hasil penelitian terhadap pelaksanaan pembelajaran geografi di kelas XI IS 2 pada KD 3.1 menunjukkan bahwa guru sudah melaksanakan transinternalisasi nilai karakter peduli lingkungan pada kegiatan pendahuluan, dan penutup. Sementara pada kegiatan inti guru lebih banyak fokus pada materi yang akan diajarkan. Nilai karakter peduli lingkungan yang dicontohkan oleh guru adalah menjaga kebersihan dan kerapian diri, menjaga kebersihan dan kerapian kelas, dan bertanggungjawab.

Pada kegiatan pendahuluan, guru menanamkan dan mencontohkan nilai karakter peduli lingkungan yaitu menjaga kerapian dan kebersihan diri. Hal ini dilihat dari pakaian yang dikenakan oleh guru yang rapi dan bersih saat memasuki kelas. Guru juga menggunakan bahasa yang santun saat menjelaskan kepada peserta didik mengenai pencapaian adiwiyata oleh sekolah, pentingnya menjaga kebersihan dan membuang sampah pada tempatnya. Tidak lupa slogan mengenai lingkungan hidup disampaikan untuk memotivasi peserta didik agar semakin cinta terhadap lingkungan. Guru mengatakan "menjaga kebersihan diri dan lingkungan adalah upaya untuk menciptakan hidup sehat."

Pada kegiatan inti, Guru memberikan apresiasi berupa tepuk tangan dan pujian dengan mengatakan "bagus" kepada peserta didik yang aktif bertanya dan menanggapi dalam diskusi di kelas. Namun diskusi yang berlangsung belum menyinggung nilai karakter peduli lingkungan.

Pada kegiatan penutup, Guru memberikan keteladanan yaitu menjaga kebersihan kelas dan membuang sampah pada tempatnya. Sebelum meninggalkan kelas, guru memeriksa meja dan kursi agar tidak ada sampah yang tertinggal.

Upaya trans-internalisasi nilai karakter peduli lingkungan yang dicontohkan dan diterapkan oleh guru dalam kegiatan pembelajaran di kelas ternyata mampu mendorong peserta didik untuk melakukan hal bermanfaat dan baik bagi lingkungan. Hal ini menunjukkan bahwa guru telah berhasil melaksanakan perannya sebagai organisator yang baik dalam proses pembelajaran afektif.

Ada beberapa upaya yang telah dilakukan peserta didik dalam rangka penyelamatan lingkungan hidup diantaranya membuang sampah pada tempatnya, menyirami tanaman, mengganti pupuk tanaman, mengganti tumbuhan yang mati dengan yang baru 
dan merawatnya, mengikuti gotongroyong di sekolah, dan ikut terlibat dalam kegiatan penanaman sejuta pohon yang dilaksanakan oleh Pertamina bersama pihak kecamatan.

Selain itu, peserta didik juga mengemukakan rencana yang ingin dilakukan dalam upaya penyelamatan lingkungan. Ada beberapa rencana yang ingin dilakukan dalam upaya penyelamatan lingkungan diantaranya melakukan penanaman pohon untuk penghijauan, melakukan pembersihan lingkungan di area selokan untuk mencegah jentik-jentik nyamuk dan menghindari penyakit malaria, melakukan pemisahan sampah berdasarkan jenisnya, menanam bunga, dan menanam tanaman obat di rumah dan di sekolah.

Antusias yang ditunjukkan peserta didik mengindikasikan bahwa peserta didik sudah menginternalisasikan nilai karakter peduli lingkungan ke dalam dirinya. Hal ini sesuai dengan tujuan internalisasi nilai karakter peduli lingkungan yakni agar peserta didik menjadi duta lingkungan bagi sekolah, rumah, dan lingkungan sekitarnya serta menjadikan sikap atau karakter tersebut menjadi tabiatnya dalam kehidupan dimanapun dia berada. Karakter peduli lingkungan tidak hanya bersifat teoritis saja tetapi dituntut sebuah tindakan nyata yang membawa perubahan baik bagi kehidupan semua orang. Zulian, Mespin (Sumber: Kompasiana, 3 Mei 2016).

\section{KESIMPULAN}

Berdasarkan hasil dan pembahasan dalam penelitian ini menunjukkan bahwa: (1) Guru belum memasukkan nilai karakter peduli lingkungan dalam RPP dilihat dari rumusan tujuan pembelajaran, pendekatan/metode pembelajaran, langkah-langkah pembelajaran, penilaian pembelajaran, dan bahan ajar. (2) Transformasi nilai dilaksanakan guru dengan memperkenalkan nilai karakter peduli lingkungan di kelas. (3) Transaksi nilai dilaksanakan guru dengan membiasakan peserta didik melaksanakan kegiatan peduli lingkungan di kelas. (4) Transinternalisasi nilai dilaksanakan guru dengan memberikan teladan dalam melaksanakan nilai karakter peduli lingkungan di kelas.

\section{DAFTAR PUSTAKA}

Samani, Muchlas., dkk. 2012. Pendidikan Karakter: Konsep dan Model. Bandung: Remaja Rosdakarya

Sahlan, Asmaun., dkk. 2016. Desain Pembelajaran Berbasis Pendidikan Karakter. Yogyakarta: Ar-ruz Media

Suasti, Yurni. 2018. "Insert Religious Model In Construction Character of Care for the Environment to the Study of Geography in Padang City-Indonesia". Journal of Islamic Studies and Culture; Vol. 6, No 1, PP 67-70. June 2018

Sugiyono. 2010. Metode Penelitian Pendidikan Pendekatan Kuantitatif, Kualitatif dan $R \& D$. Bandung: Alfabeta

Ulum, Bahrul. 2017. "Internalisasi Karakter Peduli Terhadap Lingkungan di SMAN 4 
Pasuruan". Skripsi. Universitas Islam Negeri Maulana Malik Ibrahim Malang

Zulian, Mespin. 2016. Pendidikan Karakter Cinta Lingkungan Sebagai Upaya Menyelamatkan Lingkungan. Kompasiana, 3 Mei 2016.

https://www.kompasiana.com/mesi n5727faf5f67a61f041d9697/pendi dikan-karakter-cinta-lingkungansebagai-upaya-menyelamatkanlingkungan?page $=$ all. $\quad$ Diakses pada: 2 Januari 2018 